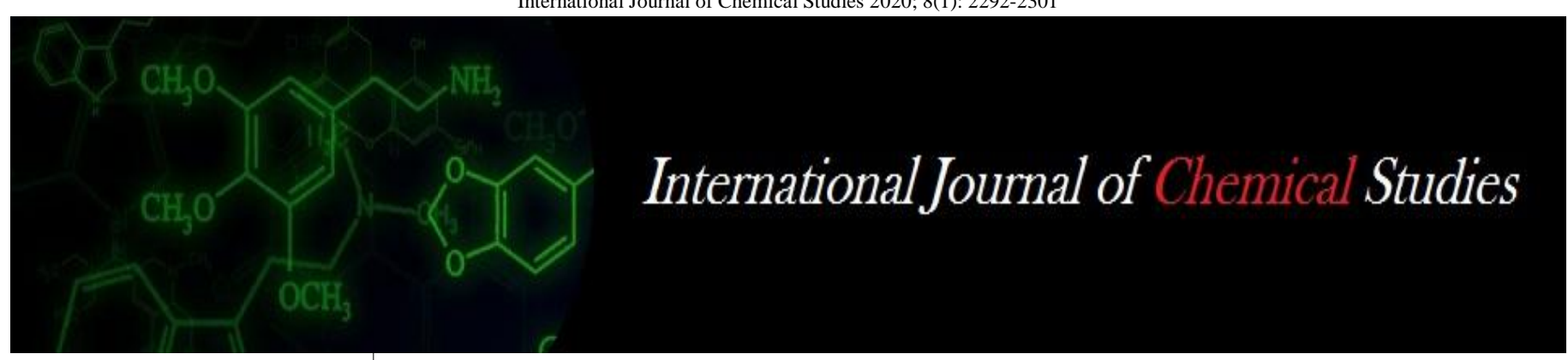

P-ISSN: 2349-8528

E-ISSN: 2321-4902

IJCS 2020; 8(1): 2292-2301

(C) 2020 IJCS

Received: 04-11-2019

Accepted: 07-12-2019

Ashish Kumar Pandey

Research Scholar, Department of Agricultural Biotechnology,

Sardar Vallabhbhai Patel

Agriculture and Technology

University Modipuram, Meerut,

Utter Pradesh, India

Rakesh Singh Sengar

Professor and Head, Department of Agricultural Biotechnology,

Sardar Vallabhbhai Patel

Agriculture and Technology

University Modipuram, Meerut,

Utter Pradesh, India
Corresponding Author: Ashish Kumar Pandey

Research Scholar, Department of Agricultural Biotechnology, Sardar Vallabhbhai Patel Agriculture and Technology University Modipuram, Meerut, Utter Pradesh, India

\section{Effect of salt stress on salt tolerant indices of morpho-physiological traits and yield attributes of lentil (Lens culinaris Medik.)}

\author{
Ashish Kumar Pandey and Rakesh Singh Sengar
}

DOI: https://doi.org/10.22271/chemi.2020.v8.i1ai.8610

\begin{abstract}
Salinity is considered in major abiotic stress creating constraints to plant growth and productivity. The knowledge of tolerant genotypes and their variability is an important requirement for success of any breeding programme. Therefore present study was attempted to screen salinity tolerance in ten lentil genotypes on the basis of their morphological, physiological and yield attributes. On the basis of experimental findings, the genotypes PDL1 were found to be highly tolerant and genotype PL07, PL04, IPL316, IPL406 was moderately tolerant whereas genotypes L4076, L4147, DPL62, DPL58 and K75 were found sensitive among studied genotypes under both salinity levels. However on the basis of yield attributes, the genotype PDL1 was found to be most tolerant among studied genotypes under both salinity levels. The genotype PDL1 will be very beneficial for the farmer belong to area which is salt affected to achieve higher pulse production.
\end{abstract}

Keywords: Salinity, lentil, yield attributes, leaf area

\section{Introduction}

Lentil (Lens culinaris Medikus) a self-pollinating, annual, cool season plant with an approximate genome size of $4 \mathrm{Gbp}$. Lentil belongs to the family Leguminaceae play a significant role in human and animal nutrition because it provides important dietary source of energy, protein, carbohydrates, fiber, minerals, vitamins and antioxidant compounds as well as diverse non-nutritional components such as protease inhibitors, tannins, $\alpha$ - galactoside oligosaccharides and phytic acid (Urbano et al., 2007) ${ }^{[52]}$. Because of its leguminous nature lentil helps in soil fertility by providing high nitrogen fixation. This in turn allows it to be used under crop rotation with cereal crop which promote sustainable agriculture.

Instability of environment rises various stresses which affect growth and yield of plants. Soil salinity is one of the main abiotic stress in semi arid and arid area. Soil salinity is the abundance of salts of sodium chlorides, calcium and magnesium sulphates and bicarbonates in soil and water. (Hoang et al., 2014) ${ }^{[19]} .830$ million hectares (ha) of soil are salt-affected globally (Munns et al., 2005) ${ }^{[38]}$ and almost two million ha of land are not usable due to increase of salinity per year (Umali, 1993) ${ }^{[51]}$. The water balance of soil is disrupted naturally as well as due to interference of human that disturbs ecology of soil and leads to increase in soil salinity progressively. Agricultural productivity in India majorly affected by soil salinity. Out of the 6.73 million ha of salt-affected soil, 3.77 million ha. Are sodic soil and 2.96 million ha. are saline soil. It is estimated that globally large area under lentil production are affected by salinity or associated condition of sodicity. Salt tolerance is a multigenic trait both physiologically as well as genetically.

Conventional breeding approaches to improve varieties against salt stress had limited success rate (Flowers, 2004; Das et al., 2015) ${ }^{[14,9]}$. Salinity stress is regulated at every stage of devlopment it is not covered under stage specific process and a single stage of plant development does not define the tolerance of all stage (Foolad, 2004) ${ }^{[16]}$.

Lentil is a major source of pulse production in many countries and undergoes substantial reduction in growth and yield above a threshold ECe of $1.7 \mathrm{dSm}^{-1}$. It exhibits stunted or slow growth under saline conditions, with its yields falling to $50 \%$ or even more of its true potential (Katerji et al. 2000) ${ }^{[18]}$. Soil salinization disturbs the texture of soil and hampers required air 
water balance for biological processes occurring in roots. This effect of salinity decreases crop yields.

Salt stress cause severe trouble to the plants morphophysiological and biochemical traits such as poor photosynthetic rates (Hasegawa et al., 2000; Munns, 2002; Ashraf and Shahbaz, 2003; Kao et al., 2003) [20, 37, 23], reduction of plant height, leaf area, leaf area index and relative water contents. Toxicity of sodium ions disturbed stability of membranes (Marschner, 1986; Gupta et al., 2002) $[33,18]$, ultimately sodium migrates to reproductive organs as well and reduces the growth and yield of plants (Munns, 2005) ${ }^{[38]}$.

The first step of salt stress causes stomatal closure and a net decrease in photosynthesis as well as production of ROS. Water potential and osmotic potential of plants become more negative with increase in salinity, whereas turgor pressure increases with increasing salinity (Parida and Das, 2005) ${ }^{[40]}$. Protoplast starts shrinking as osmotic pressure of solution rises above the cells and then plasma membrane splits from the wall. Large gaps created between the plasma membrane and the wall may get filled with solution and allow an artificial apoplastic pathway for salts to move across the root. Moreover, salinity causes increase in epidermal thickness, mesophyll thickness, palisade cell length, palisade diameter, and spongy cell diameter in leaves of bean and cotton (Longstreth and Nobel, 1979) ${ }^{[30]}$. Salinity also reduces intercellular spaces in leaves and mitochondrial cristae and causes swelling of endoplasmic reticulum and mitochondria, and fragmentation of tonoplast and cytoplasm (Mitsuya et al., 2000) ${ }^{[34]}$.

The second step of the salt stress cause ion toxicity inside the plant cell and tissues where salts compartmentalize in vacuoles and excess salts starts hindering enzymatic processes (Munns, 2005) [38]. Increased treatments of $\mathrm{NaCl}$ induces increase in $\mathrm{Na}^{+}$and $\mathrm{Cl}^{-}$and decrease in $\mathrm{Ca}^{2+}, \mathrm{K}^{+}$and $\mathrm{Mg}^{2+}$ leaves in several plants (Khan et al., 1999; Khan et al., 2000) [24, 25]. Physiological studies have indicated that during salt stress early effects (minutes to hours) on plant growth are due to water stress, whereas salt-specific effects only appear much later (days to weeks) (Denby and Gehring, 2005; Munns, 2002) $)^{[10,37]}$.

Plants adopted to live in saline environments have developed some additional biochemical and molecular strategies to cope with deleterious effects of ion accumulation in cytosol. Biochemical strategies include selective accumulation or exclusion of ions; control of ion uptake by roots and transport into leaves; and compartmentalization of ions (Munns, 2002) [37]. As a result of these alterations, the enzyme activity and metabolism are affected (De Lacerda et al., 2003) ${ }^{[11]}$. Salinity build up the collection of $\mathrm{NaCl}$ in chloroplast of higher plants, affect photosynthesis and growth rate. In several plants salt stress inhibits PS-II (Kao et al., 2003; Parida et al., 2005) [23, ${ }^{40]}$ but some studies showed that salinity has no effect on PSII (Brugnoli and Björkman, 1992; Moraleset al., 1992) ${ }^{[6]}$. The reduction of plant growth and dry matter accumulation under saline conditions have been reported in several important grain legumes (Tejera et al., 2006) ${ }^{[49]}$.

In the present study we attempt to screen ten varities of lentil for salt tolerance based on their morpho-physiological parameters and yield attributes.

\section{Materials and methods \\ Plant material and experimental design}

Ten genotypes of lentil (Lens culinaris L.) comprising of released varieties from different part of agro-climatic zone of India were selected for the present study (Table-1) and were procured from Indian Agriculture Research Institute (IARI), Pusa, New Delhi and CSUAT Kanpur. The experiment was conducted at experimental station, Department of Agriculture Biotechnology, Sardar Vallabhbhai Patel University of Agriculture \& Technology (SVPUA\&T) Meerut, India, in two consecutive years 2016-2017 and 2017-2018. The study was conducted in Randomized Blocked Design (RBD) with three replicates of each variety in control (normal condition) and two treatments (saline condition). Experimental soil was sandy loam with initial $\mathrm{pH} 6.2$ and and $\mathrm{EC}_{\mathrm{e}}$ (Electrical Conductivity of the extract of a saturated soil paste) is 1.39 $\mathrm{dSm}^{-1}$. The salinity was created at standardized level of which affects the growth parameters of lentil. The level of salinity was created at two levels $\mathrm{EC}_{\mathrm{e}} 4 \mathrm{dSm}^{-1}$ and $6 \mathrm{dSm}^{-1}$ and a control using normal soil $\left(1.39 \mathrm{dSm}^{-1}\right)$ by adding desired amount of $\mathrm{NaCl}, \mathrm{Na}_{2} \mathrm{SO}_{4}, \mathrm{CaCl}_{2} \cdot 2 \mathrm{H}_{2} \mathrm{O}$ (1: 2 :1 ratio) and mixed thoroughly in the irrigation water and irrigated the pot at pre flowering stage (30 DAS). Twenty seeds were sown in each pot and thinning was done after 20 days leaving five plants in each pot. Same fertilizer and irrigation was given to each pot. All the parameters pertaining to salinity tolerance were observed after 65 days after sowing (DAS) of plant.

\section{Meteorological observations}

During the study period meteorological data was recorded at automatic weather station of Indian Institute of Farming System Research (IIFSR), Modipuram, Meerut, India.

The meteorological data (2016-17) indicated that weekly minimum and maximum temperature during the crop season ranged from $5.6^{0 \mathrm{c}}$ to $24.3^{0 \mathrm{c}}$ and $18.5^{0 \mathrm{c}}$ to $34.5^{0 \mathrm{c}}$ respectively. Total rainfall received was $86.5 \mathrm{~mm}$ during the entire crop season and average relative humidity of morning and evening was found to be varying from $97.7 \%$ to $65.9 \%$ and total 141.3 sunshine hrs. Received during the entire crop season (Fig. 3.1). However, meteorological data (2017-18) indicated that weekly minimum and maximum temperature during the crop season ranged from $6.1^{0 \mathrm{c}}$ to $19.5^{0 \mathrm{c}}$ and $19.7^{0 \mathrm{c}}$ to $33.3^{0 \mathrm{c}}$ respectively. Total rainfall received was $13.8 \mathrm{~mm}$ during the entire crop season and average relative humidity was found to be very from 97.7 to $26.6 \%$ and $148.4 \mathrm{hrs}$ total sunshine received during the entire crop season, (Figure 3.2) calculated as standard meteorological week (SMW) during experiment conducted from October 2016 to march 2017 and October 2017 to march 2018 (Figure 1.1,1.2). 


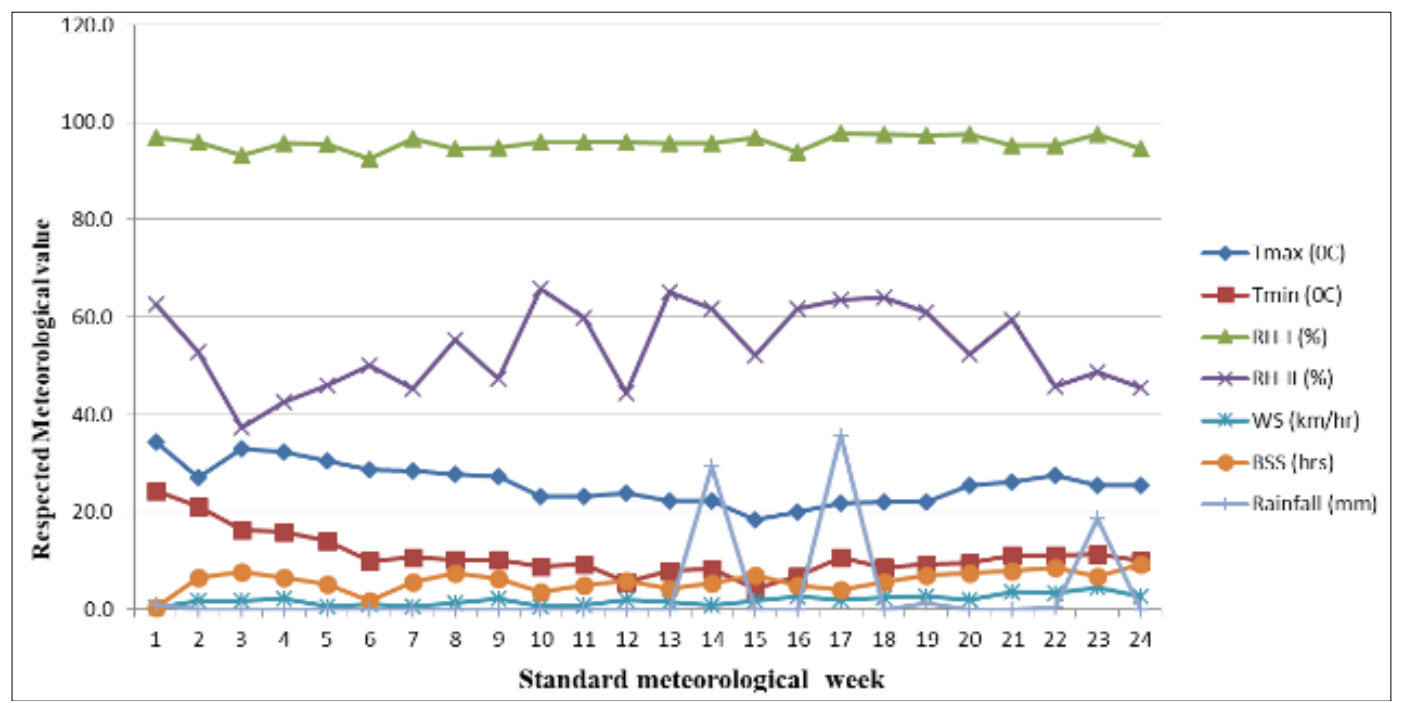

Fig 1.1: Standard meteorological weather (SMW) during October 2016 to march 2017, Line graphs indicate Weekly SMW.

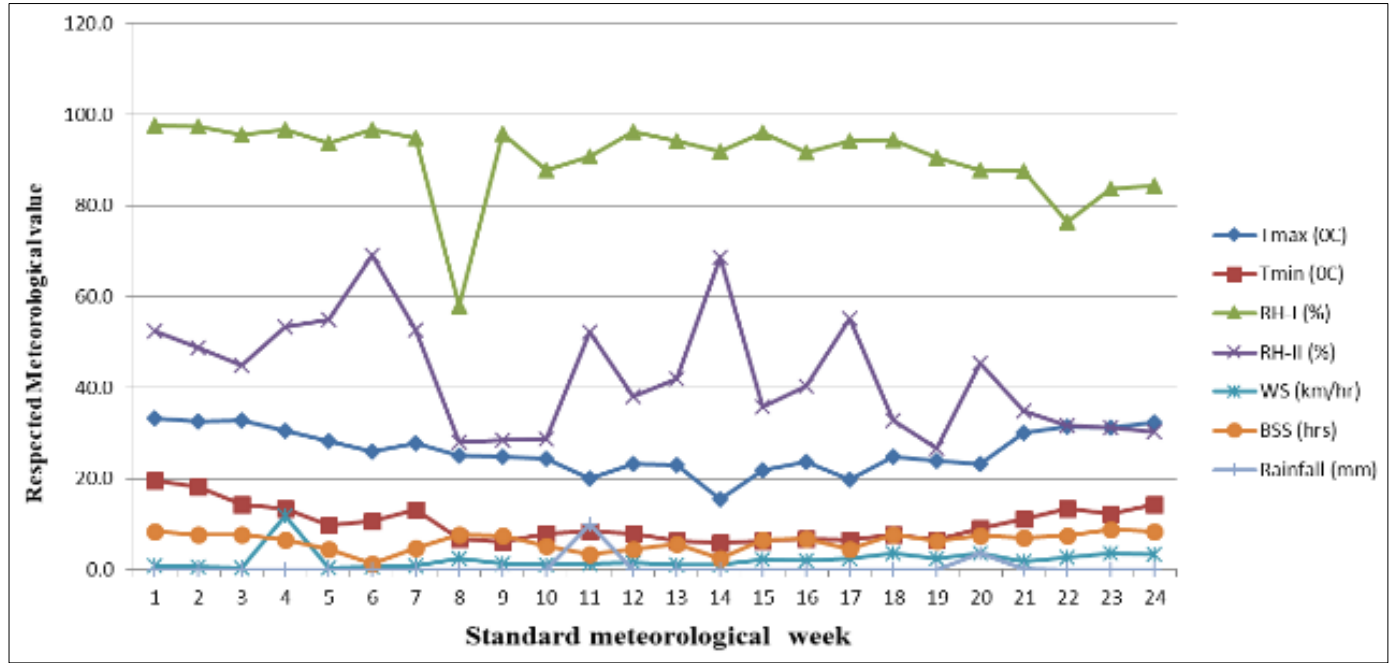

Fig 1.2: Standard meteorological weather (SMW) during October 2017 to march 2018, Line graphs indicate Weekly SMW.

\section{Measurement of Parameters}

The genotypes were observed for morphological, physiological and biochemical traits at growth phase (75 days after sowing). The investigated traits were plant height $(\mathrm{PH})$, leaf area (A) Leaf area index (LAI), relative water content (RWC), membrane stability index (MSI), Total chlorophyll content (SPAD), potassium ion accumulation $\left(\mathrm{K}^{+}\right)$, sodium ion accumulation $\left(\mathrm{Na}^{+}\right)$, pod plant ${ }^{-1}$, seed plant ${ }^{-1}$, yield plant ${ }^{-1}$ and 1000 seed weight.

\section{Estimation of Plant height}

Plant height was measured from the base of the plant to the top fully opened leaf of the main shoot at growth stage. Measurements were taken from the main shoot in each treatment tagged earlier and average height of the single plant was calculated and expressed in $\mathrm{cm}$.

\section{Estimation of Leaf area plant $\mathbf{t}^{-1}$}

Leaf area plant ${ }^{-1}$ was calculated by taking as per the method given by Mondal et al. $2013^{[35]}$

\section{Estimation of Leaf area index}

Leaf area index was calculated according to Sestak et al., $1971^{[35]}$.

$$
\text { Leaf area index }=\frac{\text { Leaf area }}{\text { Land area }}
$$

\section{Estimation of Relative Water Content}

The relative water content in recently matured leaves was determined using the method suggested by Brass and Wheatherly (1962) [5]. Completely extended leaves were removed and fresh weight of leaf (leaf discs) was recorded. Three leaves sample were collected randomly in each treatment and weighed accurately up-to fourth decimal on an electrically operated single pan analytical balance. This was considered as the fresh weight. The weighed leaf discs were allowed to float on distilled water in a petri dish and allowed to absorb water for four hours. After four hours, the leaf discs were taken out and their surface was blotted gently and weighed. This was referred to as turgid weight. Subsequently these leaf discs were dried in an oven at $70{ }^{\circ} \mathrm{C}$ for 48 hours, the dry weight was recorded and designated as dry weight. The RWC was calculated by the following formula.

$$
\text { RWC }(\%)=\frac{\text { Fresh weight }- \text { Dry weight }}{\text { Turgid weight }- \text { Dry weight }} \times 100
$$

\section{Estimation of Membrane stability index}

Membrane stability index (MSI) estimated according to Sairam (1994) ${ }^{[34]}$. Two sets of leaf tissues $(0.1 \mathrm{~g})$ were placed in $10 \mathrm{ml}$ of double-distilled water. One set was kept at $40{ }^{\circ} \mathrm{C}$ for $30 \mathrm{~min}$ and its conductivity recorded using a conductivity bridge $(\mathrm{C} 1)$. The second set was kept in a boiling water bath 
$\left(100{ }^{\circ} \mathrm{C}\right)$ for $10 \mathrm{~min}$ and its conductivity also recorded $(\mathrm{C} 2)$. The membrane stability index was calculated as:

$$
\mathrm{MSI}=[1-(\mathrm{C} 1 / \mathrm{C} 2)] \times 100
$$

\section{Estimation of chlorophyll content}

Total Chlorophyll content was measured using Chlorophyll meter SPAD-502 Plus (KONICA MINOLTA). The SPAD meter was calibrated by pressing the measuring head closed without inserting leaf and then measurement was taken for each control and treatment. The third fully expanded leaf from the top selected and measuring head of chlorophyll meter was pressed and noted. The measurement was taken three times and averaged. The concept of SPAD meter was given by Sudhakar et al., (2010) ${ }^{[46]}$.

\section{Estimation of percent Sodium $\left(\mathrm{Na}^{+}\right)$and Potassium $\left(\mathrm{K}^{+}\right)$}

Plant samples were analyzed for total $\mathrm{K}$ and $\mathrm{Na}(\%)$. For potassium and sodium analysis, plant samples were analyzed through wet digested in di-acid mixture. $\mathrm{K}$ and $\mathrm{Na}(\%)$ was determined by Flame Photometer (Jackson, 1973) [21]. For estimation of potassium and sodium percentage in plant samples di-acid digestion method was used. The mixture of concentrated $\mathrm{HClO}_{4}$ and $\mathrm{HNO}_{3}$ was used in the ratio of $(1: 2)$. $0.5 \mathrm{~g}$ of dried fine powdered leaves sample was transferred to a $200 \mathrm{ml}$ of test tube containing $10 \mathrm{ml}$ of di-acid mixture. The test tube was kept on hot plate and heated at $180-200{ }^{\circ} \mathrm{C}$ for $8 \mathrm{hr}$ for complete digestion until the dense white fumes are evolved. Further the mixture was cooled, and the volume was adjusted to $100 \mathrm{ml}$ by adding doubled distilled water in volumetric flask and filtered through Whatman filter paper. Finally, the filtrate was used for analysis as per the method described by Jackson, (1973) ${ }^{[21]}$.

\section{Estimation of Potassium (\%)}

Known quantity of plant digest in $100 \mathrm{ml}$ volumetric flask has the dilution factor of $200(0.5 \mathrm{ml}$ made up to $100 \mathrm{ml}$ gives 200 times dilution factor). The flame photometer reading was adjusted to zero with 0 ppm and with 20, 40, 60, 80, 100 ppm $\mathrm{KCl}$ solution ( $\mathrm{K}$ standard solution). Diluted solutions of plant digest were fed into the flame photometer and their readings were recorded. Concentration of $\mathrm{K}$ in diluted plant digest was estimated by referring to a standard curve of $K$ concentrations. Percentage of $\mathrm{K}$ was calculated by using the formula.

$$
\mathrm{K}(\%)=\frac{\text { ppm conc of } \mathrm{K}}{10^{6}} \times \frac{\text { volume of digest }}{\text { wt of sample (gm) }} \times \text { Dilution factor } \mathrm{x} 100
$$

\section{Estimation of Sodium (\%)}

Known quantity of plant digest in $100 \mathrm{ml}$ volumetric flask has the dilution factor of $200(0.5 \mathrm{ml}$ made upto $100 \mathrm{ml}$ gives 200 times dilution factor). The flame photometer reading was adjusted to zero with $0 \mathrm{ppm}$ and with $20,40,60,80,100 \mathrm{ppm}$ $\mathrm{NaCl}$ solution. Flame photometer reading for each diluted solution of plant digest was recorded. Concentration of $\mathrm{Na}$ in diluted plant digest was estimated by referring to standard curve. Percentage of $\mathrm{Na}$ was calculated by using the formula.

$\mathrm{Na}(\%)=\frac{\text { ppm conc of } \mathrm{Na}}{10^{6}} \times \frac{\text { volume of digest }}{\text { wt of sample }(\mathrm{gm})} \times$ Dilution factor $\mathrm{x} 100$

\section{Number of pods per plant}

Pods of each replication were counted and then average number of pods for each plant was counted
Number of seeds per plant

The total number of seeds produced by each plant were harvested separately and carefully counted.

\section{Seed yield per plant}

The seeds were separated from pods manually and then sun dried and weighted.

\section{0-seed weight}

Thousand clean sun dried seeds were counted from the seed stock obtained from the sample plants and weighted by using electronic balance.

\section{Salt Tolerant Trait Indices (STTI)}

Salt tolerant trait indices (STTI) for each of the studied trait were calculated according to the formula of Ali et al., (2007) [2].

$$
\mathrm{STI}=\frac{\text { Value of trait under stress condtion }}{\text { Value of trait under control condtion }} \times 100
$$

\section{Results and Disscussion}

The morpho-physiological traits and yield attributes are exploited under this study to collect the valuable informations. These informations are valuable for production of commercial cultivars and salt tolerant varities for semi arid and arid area which is salt affected. The experimental results of this study showed there is greater diffrence in performance of varities and can be useful in future for production of salt tolerant varities.

\section{Morphological parameters}

Plant height, leaf area and leaf area index are considered important parameters for growth under salinity stress. The results indicated a wide range of salt tolerance index (STI) for plant height ranged from 68.51 (IPL406) to 89.25 (PDL-1) with a mean of 78.34 in salinity level S-1 and 63.61 (IPL-406) to 80.40 (PDL-1) with a mean of 72.14 in salinity level S-2 in 2016-17(Table-2) while in 2017-18 ranged from 76.20 (L4076 ) to 91.69 (PDL-1) with a mean of 82.24 in salinity stage S-1 and 56.77 (DPL62) to 81.60 (PDL-1) with a mean of 70.82 in salinity level S-2(Table-2).

The salt tolerance index (STI) revealed a wide range of leaf area plant ${ }^{-1}$ ranged from 53.48 (DPL62) to 72.89 (PL04) with a mean of 61.83 in salinity level S-1 and 48.78 (DPL62) to 59.72 (PL04) with a mean of 52.90 in salinity level S-2 in 2016-17(Table-2) while in 2017-18 ranged from 55.55 (DPL62) to 74.27 (PL04) with a mean of 62.69 in salinity level 1 (S-1) and 47.95 (DPL62) to 58.28 (PL04) with a mean of 53.02 in salinity level 2 (S-2) (Table-2).

The salt tolerance index (STI) revealed a wide range of leaf area index ranged from 59.14 (DPL62) to 78.16 (PL04) with a mean of 65.96 in salinity level S-1 and 52.61 (DPL62) to 64.67 (PL04) with a mean of 58.10 in salinity level S-2 in 2016-17(Table-2) while in 2017-18 ranged from 57.87 (DPL62) to 81.78 (PL04) with a mean of 67.18 in salinity level 1 (S-1) and 55.03 (DPL-62) to 66.38 (PL04) with a mean of 58.78 in salinity level 2 (S-2) (Table-2).

The results showed reduction in plant height, leaf area, and leaf area index in salt sensitive cultivars whereas salt tolerant breeding line and cultivars showed less reduction in comparison to salt sensitive verities. The genotypes PL04 and PDL1 were found the most tolerant among studied genotypes whereas PL07, IPL316 and IPL406 were moderately tolerant and L4076, L4147, DPL62, DPL58 and K75 were found to be salt sensitive. The results found in this study were supported 
by the findings of Singh et al. (2017) ${ }^{[31]}$ and Kumawat et al., (2017) ${ }^{[19]}$. The wide range of salt tolerance indices (STI) obtained here for different traits indicate that genotypes had broad genetic base for these characters. In breeding programs, where many genotypes will be evaluated, relative salt tolerance indices (RSTI) can be exploited for these parameters to provide a ranking of the genotypes for salt tolerance.

\section{Physiological parameters}

Lentil genotypes in this study were evaluated for physiological characters viz., relative water content, membrane stability index, total chlorophyll content using SPAD meter, percent sodium ion and potassium ion. All the genotypes were evaluated for physiological features under non-saline and saline conditions during 2016-17 and 2017-18.

\section{Relative water content}

In stress conditions, physiological changes are the initial response after morphological changes against stress. When plants sense stress in the environment, some physiological changes occur. The salt tolerance index (STI) revealed a wide range of relative water content ranged from 77.70 (L-4076) to 95.79 (PDL-1) with a mean of 86.39 in salinity level (S1) and 67.90 (K-75) to 88.93 (PDL-1) with a mean of 76.95 in salinity stage S-2 in 2016-17(Table-3) while in 2017-18 ranged from 77.97 (DPL-62) to 94.56 (PDL-1) with a mean of 85.01 in salinity level $1(\mathrm{~S}-1)$ and $66.19(\mathrm{~K}-75)$ to 86.41 (PDL-1) with a mean of 76.62 in salinity level 2 (S-2) (Table3 ). The study of this parameters can produce valuable information regarding the plant tolerance ability (Munns et al., 2002; Apel and Hirt 2004; Singh et al., 2017) ${ }^{[37,3,45] .}$ There is strong coordination between various physiological response of lentil to salt stress and their tolerance mechanism such as relative water content (Sidari et al., 2008) ${ }^{[44]}$ and membrane stability index (Jamil et al., 2012) ${ }^{[22]}$. Relative water content (RWC) has been reported as an important indicator salinity stress. As the salinity increases relative water content decreases (Monem et al., 2008) ${ }^{[36]}$ and affects the balance between water supply to leaves and transpiration rate (Farquhar et al., 1989) ${ }^{[8]}$. High amount of RWC in leaf denotes that the plant can improve its inner aquatic relation under stress condition (Chakherchaman et al., 2009) ${ }^{[6]}$. Higher relative water content in tolerant genotypes influence the ability of plant to recover from salt stress, consequently maintaining the yield (Lilley et al., 1996) ${ }^{[21]}$.

\section{Membrane stability index}

Many aspects of plant growth are affected by salt stress; one of them is membrane stability index (MSI). Under salt stress, the cell membrane of lentils get damaged which leads to deleterious effect of salts, consequently decreasing growth and yield. The salt tolerance index (STI) revealed a wide range of membrane stability index percent ranged from 64.82 (DPL-62) to 90.01 (PDL-1) with a mean of 76.69 in salinity level 1 (S-1) and 46.99 (DPL-62) to 80.36 (PDL-1) with a mean of 64.48 in salinity level 2 (S-2) in 2016-17 (Table-3) while in 2017-18 ranged from 64.93 (L-4076) to 90.29 (PDL1) with a mean of 76.94 in salinity level 1 (S-1) and 48.35 (L4076 ) to 82.85 (PDL-1) with a mean of 65.22 in salinity level 2 (S-2) (Table-3). Higher membrane stability index represents the tolerance capability against salinity stress (Lee et al., 2013) ${ }^{[20]}$

\section{Total chlorophyll content using SPAD meter}

The effect of salt stress on chlorophyll content shows decreased chlorophyll content /salt stress (Lee et al., 2013)
[20]. When plants are grown under salt stress condition it leads to reduced growth and productivity. Photosynthetic activity is severely impaired due to decreased chlorophyll content, since chlorophyll content correlates directly with the growth and development of plant (Acosta-Motos et al., 2017) ${ }^{[1]}$. The salt tolerance index (STI) revealed a wide range of total chlorophyll content (SPAD value) ranged from 51.10 (L4076) to 95.24 (PDL-1) with a mean of 64.08 in salinity level $1(\mathrm{~S}-1)$ and 38.85 (L-4076) to 86.21 (PDL-1) with a mean of 48.67 in salinity level 2 (S-2) in 2016-17(Table-3). While in 2017-18 ranged from 53.56 (K75) to 93.38 (PDL-1) with a mean of 67.02 in salinity level 1 (S-1) and 48.37 (K-75) to 85.97 (PDL-1) with a mean of 57.63 in salinity level 2 (S-2) (Table-3). The decrease in chlorophyll content suggested substantial damage to the photosynthetic mechanism (Pareek et al., 1997; Lee et al., 2013) ${ }^{[31,20]}$. Our results showed that the salt treatment significantly decreased the chlorophyll content.

\section{Sodium and Potassium}

The effect of ions correlates with salt tolerance mechanism in crop plants. The concentration of sodium ion leads to salt tolerance mechanism in plants which limits the uptake or transport of ions from the root to areal parts (Lopez et al., 1999) ${ }^{[23]}$. The higher salt concentration leads hampers salt regulation mechanisms. Salt sensitive genotypes gets rapidly saturated with salt ions at lower level of salinity as compared to salt tolerant genotypes. Due to this rapid saturation plants start showing deleterious effect of sodium (Singh et al., 2017) [31]. The salt tolerance index (STI) revealed a wide range of sodium percent ranged from 472.00 (PDL-1) to 654.55 (L4076) with a mean of 584.34 in salinity at level S-1 and 528.00 (PDL-1) to 845.00 (L4147) with a mean of 730.88 in salinity level S-2 in 2016-17(Table-3). While in 2017-18 ranged from 504.35 (PDL-1) to 657.14 (L4076) with a mean of 610.90 in salinity level 1 (S-1) and 600.00 (PDL-1) to 845.45 (DPL-62) with a mean of 764.74 in salinity stage 2 (S2). (Table-3) In the present investigation, at higher concentration sodium uptake increases in salt sensitive genotypes as compared to tolerant genotypes. The genotype which accumulated higher amounts of sodium was L4076, L4147, K75, DPL62, DPL58 whereas PDL1 showed the least uptake. Hence, we can say that tolerant genotypes have better mechanism to avoid salt accumulation and bypass detrimental effect of sodium on plant metabolism. This observation is in accordance to those observed in other species (Marshner 1986; Femandes et al., 1994) ${ }^{[25,9]}$.

The salt tolerance mechanism can be correlated with selective uptake of potassium over sodium (Wenxue et al., 2003) ${ }^{[41]}$. The salt tolerance index (STI) revealed a wide range of potassium percent ranged from 35.07 (DPL-62) to 69.44 (PDL-1) with a mean of 53.42 in salinity at stage S-1 and 20.15 (DPL-62) to 51.06 (PDL-1) with a mean of 37.32 in salinity stage S-2 in 2016-17 (Table-3). While in 2017-18 ranged from 37.34 (L-4076) to 70.01 (PDL-1) with a mean of 54.01 in salinity stage 1 (S-1) and 20.18 (DPL-62) to 50.08 (PDL-1) with a mean of 36.99 in salinity stage 2 (S-2) (Table$3)$. The salt tolerance mechanism revealed by the selective uptake of potassium and not sodium was considered one of the important physiological mechanism. The deficiency of potassium enhances sodium toxicity (Flower et al., 1983). In present study, it was also found that potassium content decreased with increasing sodium concentration, it indicates antagonistic nature between the absorption of sodium and potassium. In tolerant genotype potassium concentration 
decreased marginally with less increase of sodium as compared to sensitive genotypes. This suggests that tolerant genotypes have better regulation of potassium concentration with proper maintenance of sodium concentration. Thus, tolerant genotype can maintain relatively higher potassium level. The higher potassium concentration is related with better growth and higher seed yield.

The wide range of relative salt tolerance indices found in this study for different traits would be fruitful in breeding programs for genotype ranking for salt tolerance. Based on these physiological parameters, PDL1, PL04, PL07, IPL316 showed higher relative salt tolerance indices whereas L4076, L4147, K75, DPL62 showed lower range of relative salt tolerance indices and DPL58, IPL406 had moderate range of relative salt tolerance indices. Therefore, on the basis of relative salt tolerance indices, genotypes can be classified as tolerant, moderately tolerant and sensitive for salinity. Our results are in agreement with Sidariet al., (2008) ${ }^{[36]}$; Monem et al., (2008) ${ }^{[28]}$ for relative water content and Monem et al., (2008) [36]; regarding chlorophyll content. Similar findings were reported for sodium and potassium relationship by Turan

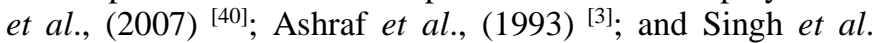
$(2017)^{[31]}$.

\section{Yield attributes}

Salinity stress disturbs the metabolic activity of plants (Dua 1998) ${ }^{[7]}$ and the uptake of sodium by plant ultimately leads to translocation of sodium in reproductive organs that disturbs pod per plant, seed per plant and seed yield per plant statistics which ultimately affects the seed weight of lentil. Tolerant genotypes have ability to check the uptake of sodium which leads to lower level of sodium translocation to the reproductive organs hence resulting in greater number of pods, seeds, and seed yield per plant and 1000 seed weight is better in comparison to those of sensitive genotypes which have poorer sodium uptake regulation. Higher sodium levels cause necrosis of leaves which affect the life of leaflets ultimately resulting in yield reduction (Tester and Davenport 2003) ${ }^{[39]}$.

\section{Pod Plant ${ }^{-1}$}

The salt tolerance index (STI) revealed a wide range of Pod/Plant ranged from 32.00 (L-4147) to 63.59 (PDL-1) with a mean of 41.81 in salinity level S-1 and 22.00 (K-75) to 48.68 (PDL-1) with a mean of 30.65 in salinity level S-2 in 2016-17 (Table-4). While in 2017-18 ranged from 32.65 (L4147 ) to 64.44 (PDL-1) with a mean of 42.68 in salinity level 1 (S-1) and 22.42 (K-75) to 48.68 (PDL-1) with a mean of 31.34 in salinity level 2 (S-2) (Table-4).

\section{No. of seed Plant ${ }^{-1}$}

The salt tolerance index (STI) revealed a wide range of No. of seed/Plant ranged from 35.00 (K-75) to 71.86 (PDL-1) with a mean of 47.92 in salinity level S-1 and $24.00(\mathrm{~K}-75)$ to 50.72 (PDL-1) with a mean of 33.27 in salinity level S-2 in 201617(Table-4). While in 2017-18 ranged from 34.62 (K-75) to 74.52 (PDL-1) with a mean of 48.53 in salinity level 1 (S-1) and $23.68(\mathrm{~K}-75)$ to 52.54 (PDL-1) with a mean of 33.63 in salinity level 2 (S-2) (Table-4).

\section{Seed yield Plant ${ }^{-1}$}

The salt tolerance index (STI) revealed a wide range of seed yield/Plant ranged from 32.69 (L-4147) to 67.59 (PDL-1) with a mean of 42.26 in salinity level S-1 and 22.00 (K-75) to 67.59 (PDL-1) with a mean of 33.17 in salinity level S-2 in 2016-17(Table-4). While in 2017-18 ranged from 32.19 (L4147 ) to 69.93 (PDL-1) with a mean of 42.17 in salinity level 1 (S-1) and 20.00 (K-75) to 69.93 (PDL-1) with a mean of 32.05 in salinity level 2 (S-2) (Table-4).

\section{0 seed weight}

The salt tolerance index (STI) revealed a wide range of 1000 seed weight ranged from 36.18 (K-75) to 84.65 (PDL-1) with a mean of 54.41 in salinity level S-1 and 26.38 (DPL-62) to 83.28 (PDL-1) with a mean of 44.03 in salinity level S-2 in 2016-17(Table-4). While in 2017-18 ranged from 36.04 (K$75)$ to 85.53 (PDL-1) with a mean of 44.08 in salinity level 1 (S-1) and 26.25 (DPL-62) to 84.13 (PDL-1) with a mean of 44.08 in salinity level 2 (S-2) (Table-4).

The relative salt tolerance indices in this study suggest that sodium concentrations have negative impact on yield and yield related attributes. Based on yield attributes PDL1 were found most tolerant genotypes. The results of present study are in the agreement with study of Ashraf et al., (1993) ${ }^{[3]}$, Gadala et al., (2007) [13], Mondal et al., (2013) ${ }^{[35]}$, Tesfaye et al. (2014) ${ }^{[38]}$, Singh et al., (2017) ${ }^{[31]}$. The above study is useful in assessment of salt tolerant genotype of lentil. Our study showing similarity with other researchers and their Finding in different plant species like chickpea, faba bean.

\section{Group ranking and score based on Salt tolerance index (STI)}

All the ten studied lentil genotypes were ranked according to Salinity tolerant index (STI) and two salinity levels S1 and S2 and positioned of group rank are shown in table (Table-5, 6, 7). The Performance of PDL-1 in STI scores and ranking was more superior in all the studied traits with moderate ranking of PL07 and PL04.

Table 1: Lentil genotypes used in this study

\begin{tabular}{|c|c|c|}
\hline Sr. No. & Genotypes & Source \\
\hline 1 & L4076 & IARI Pusa \\
\hline 2 & L4147 & IARI Pusa \\
\hline 3 & PL04 & IARI Pusa \\
\hline 4 & PL07 & IARI Pusa \\
\hline 5 & PDL1 & IARI Pusa \\
\hline 6 & DPL62 & IARI Pusa \\
\hline 7 & DPL58 & IARI Pusa \\
\hline 8 & IPL406 & CSAU Kanpur \\
\hline 9 & K75 & IARI Pusa \\
\hline 10 & IPL316 \\
\hline
\end{tabular}


Table 2: Relative salt tolerance indices at Salinity Level S-1 \& Salinity Level S-2 of following traits studied for year 2016-17 (I) \& $2017-18$ (II) in Lentils

\begin{tabular}{|c|c|c|c|c|c|c|c|c|c|c|c|c|}
\hline \multirow{3}{*}{ Genotypes } & \multirow{2}{*}{\multicolumn{2}{|c|}{$\begin{array}{c}\text { Plant height }(\mathrm{cm}) \\
\text { I }\end{array}$}} & \multirow{2}{*}{\multicolumn{2}{|c|}{$\begin{array}{c}\text { Plant height (cm) } \\
\text { II }\end{array}$}} & \multirow{2}{*}{\multicolumn{2}{|c|}{\begin{tabular}{|c} 
Leaf Area Plant \\
I
\end{tabular}}} & \multirow{2}{*}{\multicolumn{2}{|c|}{$\begin{array}{c}\text { Leaf Area Plant }^{-1}\left(\mathrm{~cm}^{2}\right) \\
\text { II }\end{array}$}} & \multirow{2}{*}{\multicolumn{2}{|c|}{\begin{tabular}{|c|} 
Leaf Area Index \\
I
\end{tabular}}} & \multirow{2}{*}{\multicolumn{2}{|c|}{\begin{tabular}{|c|} 
Leaf Area Index \\
II
\end{tabular}}} \\
\hline & & & & & & & & & & & & \\
\hline & $\mathbf{S}_{1}$ & $\mathbf{S}_{2}$ & $S_{1}$ & $\mathbf{S}_{2}$ & $S_{1}$ & $\mathbf{S}_{2}$ & $\mathbf{S}_{1}$ & $\mathbf{S}_{2}$ & $\mathbf{S}_{1}$ & $\mathbf{S}_{2}$ & $\mathbf{S}_{1}$ & $\mathbf{S}_{2}$ \\
\hline L4076 & 74.95 & 69.78 & 76.20 & 68.74 & 62.44 & 53.89 & 63.41 & 54.95 & 65.20 & 58.80 & 63.24 & 56.72 \\
\hline L4147 & 75.32 & 71.33 & 77.28 & 70.88 & 58.44 & 52.94 & 59.54 & 51.67 & 63.56 & 59.11 & 66.19 & 58.20 \\
\hline PL04 & 81.47 & 74.72 & 84.52 & 73.41 & 72.89 & 59.72 & 74.27 & 58.28 & 78.16 & 64.67 & 81.78 & 66.38 \\
\hline PL07 & .16 & 77.2 & 85.91 & 75.15 & 67.25 & 52.03 & 66.23 & 53.54 & 70.17 & 58.35 & 73.51 & 60.84 \\
\hline PDL1 & .25 & 80.44 & 91.69 & 81.62 & 68.69 & 54.54 & 69.07 & 55.20 & 71.76 & 59.50 & 75.09 & 62.09 \\
\hline DPL62 & 71.87 & 66.15 & 76.91 & 56.77 & 53.48 & 48.78 & 55.55 & 47.95 & 59.14 & 52.61 & 57.87 & 55.03 \\
\hline DPL58 & 82.25 & 72.27 & 83.31 & 72.06 & 57.29 & 48.90 & 58.32 & 49.71 & 61.60 & 54.40 & 59.88 & 55.53 \\
\hline IPL406 & 68.51 & 63.61 & 78.37 & 61.02 & 65.76 & 58.02 & 67.28 & 57.54 & 68.28 & 62.83 & 70.38 & 60.64 \\
\hline K75 & 72.56 & 67.75 & 79.28 & 71.70 & 54.46 & 49.99 & 56.34 & 50.55 & 60.51 & 55.80 & 60.97 & 56.89 \\
\hline IPL316 & 84.11 & 78.24 & 88.94 & 76.9 & 57.63 & 50.19 & 56.94 & 49.87 & 61.25 & 55.00 & 62.90 & 55.48 \\
\hline
\end{tabular}

S1- Salinity $\left(\mathrm{EC}_{\mathrm{iw}}=4.00 \mathrm{dSm}^{-1}\right), \mathrm{S} 2-$ Salinity $\left(\mathrm{EC}_{\mathrm{iw}}=6.00 \mathrm{dSm}^{-1}\right)$.

Table 3: Relative salt tolerance indices at Salinity Level S-1 \& Salinity Level S-2 of following traits studied for year 2016-17 (I) \& $2017-18$ (II) in Lentils

\begin{tabular}{|c|c|c|c|c|c|c|c|c|c|c|c|c|c|c|c|c|c|c|c|c|}
\hline \multirow{3}{*}{ Genotypes } & \multirow{2}{*}{\multicolumn{2}{|c|}{\begin{tabular}{|c|} 
RWC (\%) \\
\end{tabular}}} & \multirow{2}{*}{\multicolumn{2}{|c|}{\begin{tabular}{|c|} 
RWC (\%) \\
II
\end{tabular}}} & & \multicolumn{2}{|c|}{ MSI (\%) } & \multicolumn{2}{|c|}{$\begin{array}{l}\text { Total Chlorophyll } \\
\text { Content }\left(\mu \mathrm{g} / \mathrm{cm}^{2}\right) \\
\end{array}$} & \multirow{2}{*}{\multicolumn{2}{|c|}{$\begin{array}{l}\text { Total Chlorophyll } \\
\text { Content }\left(\mu \mathrm{g} / \mathrm{cm}^{2}\right) \\
\text { II }\end{array}$}} & \multicolumn{2}{|c|}{$\mathrm{Na}^{+}(\%)$} & \multicolumn{2}{|c|}{$\mathrm{Na}^{+}(\%)$} & \multicolumn{2}{|c|}{$\mathbf{K}^{+}(\%)$} & \multicolumn{2}{|c|}{$\mathbf{K}^{+}(\%)$} \\
\hline & & & & & I & & $\bar{I}$ & II & & & & & $\mathbf{I}$ & & $\overline{\text { II }}$ & I & & I & & II \\
\hline & $\mathbf{S}_{1}$ & $\mathbf{S}_{2}$ & $\mathbf{S}_{1}$ & $\mathbf{S}_{2}$ & $S_{1}$ & $\mathbf{S}_{2}$ & $\mathbf{S}_{1}$ & $\mathbf{S}_{2}$ & $S_{1}$ & $\mathbf{S}_{2}$ & $\mathbf{S}_{1}$ & $\mathbf{S}_{2}$ & S1 & S2 & S1 & S2 & S1 & S2 & S1 & S2 \\
\hline L4076 & 77.70 & 74.61 & 79.15 & 73.08 & 64.94 & 47.79 & 64.93 & 48.35 & 51.10 & 38.85 & 58.79 & 50.75 & 654.45 & 813.64 & 657.14 & 842.86 & 8.32 & 25.06 & 37.34 & 24.46 \\
\hline L4147 & \begin{tabular}{|l|}
83.27 \\
\end{tabular} & 75.27 & 80.18 & 75.20 & 65.74 & 48.54 & 66.30 & \begin{tabular}{|l|}
50.32 \\
\end{tabular} & 52.63 & 40.00 & 60.24 & 51.29 & 645.01 & 845.00 & 625.00 & 835.00 & \begin{tabular}{|l|}
40.16 \\
\end{tabular} & 28.35 & 39.67 & 27.83 \\
\hline PL04 & 89.92 & 79.63 & 88.68 & 79.65 & 84.85 & 76.92 & 85.55 & 77.12 & 69.35 & 48.30 & 66.66 & 56.17 & 610.09 & 765.02 & 621.05 & 736.16 & 65.43 & 44.64 & 64.64 & 43.38 \\
\hline PL07 & 91.56 & 80.44 & 91.70 & 82.54 & 85.73 & 77.79 & 86.79 & 78.29 & 70.88 & 50.00 & 74.90 & 63.19 & 571.43 & 714.29 & 621.00 & 700.00 & 66.94 & 48.68 & \begin{tabular}{|l|}
65.41 \\
\end{tabular} & 47.60 \\
\hline PDL1 & \begin{tabular}{|l|}
95.79 \\
\end{tabular} & 88.93 & 94.56 & 86.41 & 90.01 & 80.36 & 90.29 & 82.85 & 95.24 & 86.21 & 93.38 & 85.97 & 472.06 & 528.00 & 504.35 & 600.00 & 69.44 & 51.06 & 70.01 & 50.08 \\
\hline DPL62 & 82.22 & 70.65 & 77.97 & 72.26 & 64.82 & 46.99 & 66.17 & 49.84 & 53.76 & 41.19 & 57.61 & 49.14 & 625.01 & 812.50 & 631.82 & 845.45 & 35.07 & 20.15 & 42.59 & 20.18 \\
\hline DPL58 & 90.45 & 78.12 & 86.05 & 78.38 & 83.79 & 73.75 & 83.94 & 73.39 & 68.49 & 49.09 & 67.94 & 55.54 & 613.63 & 772.73 & 628.57 & 804.76 & 63.04 & 43.65 & 63.03 & 43.36 \\
\hline IPL406 & 81.40 & \begin{tabular}{|l|}
72.71 \\
\end{tabular} & 81.34 & 70.84 & 71.43 & 58.82 & 70.99 & \begin{tabular}{|l|}
58.19 \\
\end{tabular} & 51.55 & 40.73 & 61.47 & 54.66 & 550.02 & 718.18 & 626.32 & \begin{tabular}{|l|}
789.47 \\
\end{tabular} & \begin{tabular}{|l|}
47.41 \\
\end{tabular} & 31.85 & \begin{tabular}{|l|}
47.53 \\
\end{tabular} & 33.6 \\
\hline K75 & 78.41 & 67.90 & 79.97 & 66.19 & 67.24 & 55.56 & 66.10 & \begin{tabular}{|l|}
54.80 \\
\end{tabular} & 55.55 & 39.15 & 53.56 & 48.37 & 604.76 & 771.43 & 633.33 & 790.48 & \begin{tabular}{|l|}
41.19 \\
\end{tabular} & 30.24 & 43.74 & 31.01 \\
\hline IPL316 & 93.15 & 81.27 & 90.49 & 81.63 & 88.36 & 78.26 & 88.34 & 79.10 & 72.27 & 53.19 & 75.65 & 61.27 & 496.02 & 568.00 & 571.43 & 676.19 & 67.22 & 49.54 & 66.14 & 48.42 \\
\hline
\end{tabular}

Table 4: Relative salt tolerance indices at Salinity Level S-1 \& Salinity Level S-2 of following traits studied for year 2016-17 (I) \& $2017-18$ (II) in Lentils

\begin{tabular}{|c|c|c|c|c|c|c|c|c|c|c|c|c|c|c|c|c|}
\hline \multirow{3}{*}{ Genotypes } & \multirow{2}{*}{\multicolumn{2}{|c|}{ Pod Plant $^{-1}$}} & \multirow{2}{*}{\multicolumn{2}{|c|}{$\begin{array}{c}\text { Pod Plant }^{-1} \\
\text { II }\end{array}$}} & \multirow{2}{*}{\multicolumn{2}{|c|}{$\begin{array}{c}\begin{array}{c}\text { No. of Seed } \\
\text { Plant }^{-1}\end{array} \\
\text { I } \\
\end{array}$}} & \multirow{2}{*}{\multicolumn{2}{|c|}{$\begin{array}{c}\begin{array}{c}\text { No. of Seed } \\
\text { Plant }^{-1}\end{array} \\
\text { II } \\
\end{array}$}} & \multirow{2}{*}{\multicolumn{2}{|c|}{$\begin{array}{c}\begin{array}{l}\text { Seed yield } \\
\text { Plant }^{-1}(\mathrm{~g})\end{array} \\
\text { I }\end{array}$}} & \multicolumn{4}{|c|}{ Seed yield Plant ${ }^{-1}(g)$} & \multirow{3}{*}{$\begin{array}{c}\begin{array}{l}1000 \text { Seed } \\
\text { weight }(g)\end{array} \\
\text { I } \\
\text { S1 }\end{array}$} & \multirow{3}{*}{$\begin{array}{c}\begin{array}{c}\text { 1000 Seed } \\
\text { weight }(\mathrm{g})\end{array} \\
\mathrm{I} \\
\text { S2 }\end{array}$} \\
\hline & & & & & & & & & & & & & II & & & \\
\hline & S1 & S2 & S1 & S2 & S1 & S2 & S1 & S2 & S1 & S2 & S1 & S2 & S1 & S2 & & \\
\hline L4076 & 36.82 & 24.55 & 37.23 & 25.04 & 40.95 & 28.67 & 40.86 & 28.53 & 36.86 & 24.58 & 36.69 & 23.19 & 17.26 & 11.28 & 43.78 & 28.45 \\
\hline L4147 & 32.00 & 26.23 & 32.65 & 26.39 & 35.72 & 26.54 & 36.00 & 26.68 & 32.69 & 32.69 & 32.19 & 32.19 & 11.86 & 9.35 & 53.23 & 11.77 \\
\hline PL04 & 47.63 & 35.72 & 49.16 & 37.07 & 47.68 & 36.98 & 47.29 & 36.62 & 46.68 & 35.01 & 46.93 & 33.12 & 18.02 & 13.32 & 74.19 & 54.56 \\
\hline PL07 & 45.69 & 32.78 & 47.00 & 33.91 & 52.73 & 38.80 & 56.05 & 41.18 & 45.81 & 32.86 & 47.57 & 32.54 & 17.76 & 12.15 & 66.13 & 45.01 \\
\hline PL & 9 & 48.68 & 64. & $\delta$ & 71.86 & 50.72 & 74.52 & 52 & 67.5 & 67.59 & 69 & 3 & 20.47 & 20.14 & 53 & 4.13 \\
\hline DPL62 & 34.00 & 25.00 & 34.68 & 25.65 & 48.00 & 27.00 & 47.19 & 26.46 & 34.00 & 25.00 & 33.84 & 24.13 & 12.34 & 8.78 & 37.12 & 26.25 \\
\hline DPL58 & 32.46 & 23.61 & 33.55 & 24.58 & 47.25 & 26.70 & 49.16 & 27.69 & 33.88 & 24.64 & 33.20 & 23.21 & 13.47 & 10.60 & 41.59 & 32.62 \\
\hline IPL406 & 44.00 & 33.00 & 45.32 & 34.15 & 46.91 & 34.47 & 47.98 & 35.20 & 42.13 & 31.60 & 42.07 & 30.58 & 14.99 & 12.45 & 55.54 & 46.00 \\
\hline K75 & 36.00 & 22.00 & 36.29 & 22.42 & 35.00 & 24.00 & 34.62 & 23.68 & 36.00 & 22.00 & 35.20 & 20.00 & 11.16 & 10.31 & 36.04 & 33.26 \\
\hline IPL316 & 46.00 & 35.00 & 46.56 & 35.60 & 53.13 & 38.83 & 51.69 & 37.71 & 47.02 & 35.78 & 44.17 & 31.67 & 16.05 & 14.69 & 53.42 & 48.81 \\
\hline
\end{tabular}

S1- Salinity $\left(\mathrm{EC}_{\mathrm{iw}}=4.00 \mathrm{dSm}^{-1}\right), \mathrm{S} 2-$ Salinity $\left(\mathrm{EC}_{\mathrm{iw}}=6.00 \mathrm{dSm}^{-1}\right)$.

Table 5: Ranking of genotypes by using average STI Scores of various Morphological and physiological characters (2016-17)

\begin{tabular}{|c|c|c|c|c|c|c|c|c|c|}
\hline \multirow{3}{*}{ S. No. } & \multirow{3}{*}{ Genotype } & \multicolumn{4}{|c|}{ Based on PH, LAP ${ }^{-1}$, LAI } & \multicolumn{4}{|c|}{ Based on RWC, MSI and SPAD, $\mathrm{Na}^{+}, \mathrm{K}^{+}$} \\
\hline & & \multicolumn{2}{|c|}{ S-1 } & \multicolumn{2}{|c|}{ S-2 } & \multicolumn{2}{|c|}{ S-1 } & \multicolumn{2}{|c|}{ S-2 } \\
\hline & & GR & TR & GR & TR & GR & TR & GR & TR \\
\hline 1 & L4076 & 3 & Susceptible & 3 & Susceptible & 3 & Susceptible & 3 & Susceptible \\
\hline 2 & L4147 & 3 & Susceptible & 3 & Susceptible & 3 & Susceptible & 3 & Susceptible \\
\hline 3 & PL04 & 1 & Tolerant & 2 & Moderate & 1 & Tolerant & 1 & Tolerant \\
\hline 4 & PL07 & 1 & Tolerant & 1 & Tolerant & 1 & Tolerant & 1 & Tolerant \\
\hline 5 & PDL1 & 1 & Tolerant & 1 & Tolerant & 1 & Tolerant & 1 & Tolerant \\
\hline 6 & DPL62 & 3 & Susceptible & 3 & Susceptible & 3 & Susceptible & 3 & Susceptible \\
\hline 7 & DPL58 & 2 & Moderate & 2 & Moderate & 2 & Moderate & 2 & Moderate \\
\hline 8 & IPL406 & 3 & Susceptible & 3 & Susceptible & 2 & Moderate & 2 & Moderate \\
\hline 9 & K-75 & 3 & Susceptible & 3 & Susceptible & 3 & Susceptible & 3 & Susceptible \\
\hline 10 & IPL316 & 1 & Tolerant & 1 & Tolerant & 1 & Tolerant & 1 & Tolerant \\
\hline
\end{tabular}

GR-Genotype rank; TR-Tolerance rank 
Table 6: Ranking of genotypes by using average STI Scores of various Morphological and physiological characters (2017-18)

\begin{tabular}{|c|c|c|c|c|c|c|c|c|c|}
\hline \multirow{3}{*}{ S. No. } & \multirow{3}{*}{ Genotype } & \multicolumn{4}{|c|}{ Based on PH, LAP ${ }^{-1}$, LAI } & \multicolumn{4}{|c|}{ Based on RWC, MSI, Chlorophyll (SPAD), $\mathrm{Na}^{+}, \mathrm{K}^{+}$} \\
\hline & & \multicolumn{2}{|r|}{ S-1 } & \multicolumn{2}{|c|}{ S-2 } & \multirow[b]{2}{*}{ GR } & \multirow[b]{2}{*}{ TR } & \multirow[b]{2}{*}{ GR } & \multirow[b]{2}{*}{ TR } \\
\hline & & GR & TR & & & & & & \\
\hline 1 & L4076 & 3 & Susceptible & 3 & Susceptible & 3 & Susceptible & 3 & Susceptible \\
\hline 2 & L4147 & 3 & Susceptible & 3 & Susceptible & 3 & Susceptible & 3 & Susceptible \\
\hline 3 & PL04 & 1 & Tolerant & 2 & Moderate & 1 & Tolerant & 1 & Tolerant \\
\hline 4 & PL07 & 1 & Tolerant & 1 & Tolerant & 1 & Tolerant & 1 & Tolerant \\
\hline 5 & PDL1 & 1 & Tolerant & 1 & Tolerant & 1 & Tolerant & 1 & Tolerant \\
\hline 6 & DPL62 & 3 & Susceptible & 3 & Susceptible & 3 & Susceptible & 3 & Susceptible \\
\hline 7 & DPL58 & 2 & Moderate & 2 & Moderate & 2 & Moderate & 2 & Moderate \\
\hline 8 & IPL406 & 3 & Susceptible & 3 & Susceptible & 2 & Moderate & 2 & Moderate \\
\hline 9 & K-75 & 3 & Susceptible & 3 & Susceptible & 3 & Susceptible & 3 & Susceptible \\
\hline 10 & IPL316 & 1 & Tolerant & 1 & Tolerant & 1 & Tolerant & 1 & Tolerant \\
\hline
\end{tabular}

GR-Genotype rank; TR-Tolerance rank

Table 7: Ranking of genotypes by using average STI Scores of various Yield Attributes (2016-17) and (2017-18)

\begin{tabular}{|c|c|c|c|c|c|c|c|c|c|}
\hline \multirow{2}{*}{ S. No. } & \multirow{2}{*}{ Genotype } & \multicolumn{4}{|c|}{ 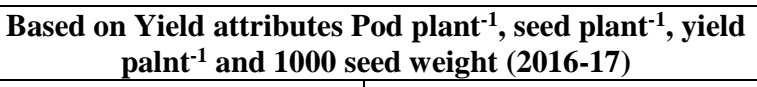 } & \multicolumn{4}{|c|}{$\begin{array}{c}\text { Based on Yield attributes Pod plant }{ }^{-1} \text {, seed plant }{ }^{-1} \text {, yield } \\
\text { palnt }^{-1} \text { and } 1000 \text { seed weight }(2017-18)\end{array}$} \\
\hline & & GR & TR & GR & TR & GR & TR & GR & TR \\
\hline 1 & L4076 & 3 & Susceptible & 3 & Susceptible & 3 & Susceptible & 3 & Susceptible \\
\hline 2 & L4147 & 3 & Susceptible & 3 & Susceptible & 3 & Susceptible & 3 & Susceptible \\
\hline 3 & PL04 & 2 & Moderate & 2 & Moderate & 2 & Moderate & 2 & Moderate \\
\hline 4 & PL07 & 2 & Moderate & 2 & Moderate & 2 & Moderate & 2 & Moderate \\
\hline 5 & PDL1 & 1 & Tolerant & 1 & Tolerant & 1 & Tolerant & 1 & Tolerant \\
\hline 6 & DPL62 & 3 & Susceptible & 3 & Susceptible & 3 & Susceptible & 3 & Susceptible \\
\hline 7 & DPL58 & 3 & Susceptible & 3 & Susceptible & 3 & Susceptible & 3 & Susceptible \\
\hline 8 & IPL406 & 2 & Moderate & 2 & Moderate & 2 & Moderate & 2 & Moderate \\
\hline 9 & $\mathrm{~K}-75$ & 3 & Susceptible & 3 & Susceptible & 3 & Susceptible & 3 & Susceptible \\
\hline 10 & IPL316 & 2 & Moderate & 2 & Moderate & 2 & Moderate & 2 & Moderate \\
\hline
\end{tabular}

GR-Genotype rank; TR-Tolerance rank

\section{Conclusion and Recommendations}

On the basis of above findings, following useful conclusions, both having fundamental and applied values, may be drawn. The increased in salinity stress leads to disturbance in various studied characters such as morphological traits like (Plant height, leaf area palnt $^{-1}$, leaf area index), Physiological parameters like (RWC, MSI, Total Chlorophyll contents, $\mathrm{Na}^{+}$ and $\mathrm{K}^{+}$contents and yield attributes. On the basis of these studied parameters PDL1 were found most tolerant genotypes whereas PL04, PL07, IPL406 and IPL316 were found moderately tolerant genotypes although L4076, L4147, DPL62 and DPL58 were more susceptible genotypes. The overall performance of PDL1 under salt stress was found superior than among studied genotypes. The genotype PDL1 will be very beneficial for the farmer belong to area which is salt affected up to $6 \mathrm{dSm}^{-1}$ to achieve higher pulse production. These attributes can be used for screening tool for salinity tolerance in other cultivars as well.

\section{References}

1. Acosta-Motos JR, Ortuño MF, Bernal-Vicente A, Vivancos PD, Sanchez-Blanco MJ, Hernandez JA. Plant Responses to Salt Stress: Adaptive Mechanisms Agronomy. 2017; 7(1):18.

2. Ali Z, Salam A, Azhar FM, Khan IA. Genotypic variation in salinity tolerance among spring and winter wheat (Triticum aestivum L.) accessions. South Afr. J Bot. 2007; 73:70-75.

3. Apel K, Hirt H. Reactive oxygen species: metabolism, oxidative stress, and signal transduction. Ann Rev Plant Biol. 2004; 55:373-399.

4. Ashraf M, Waheed A. Responses of Some Local/Exotic Accessions of Lentil (Lens culinaris Medic.) to Salt
Stress. Journal of Agronomy and Crop Science. 1993; 170:103-112.

5. Brass HD, Weatherley PE. A re-examination of the relative turgidity technique for estimating water deficits in leaves. Aus. J Bio. Sci. 1962; 15:143-28.

6. Brugnoli E, Björkman O. Growth of cotton under continuous salinity stress: influence on allocation pattern, stomatal and non-stomatal components of photosynthesis and dissipation of excess light energy. Planta. 1992; 187:335-345.

7. Chakherchaman A, Mostafaei S, Hossein I, Leila R, Eivazian M. Evaluation of drought tolerance in lentil advanced genotypes in Ardabil region Iran. Journal of Food, Agriculture and Environment, 2009, 7.

8. Dua RP. Salinity tolerance in chickpea (Cicer arietinum L.) Indian J Plant Physiol. 1998; 3:102-106.

9. Das G, Rao GJN. Molecular marker assisted gene stacking for biotic and abiotic stress resistance genes in an elite rice cultivar. Front. Plant Sci. 2015; 6:698. doi: 10.3389/fpls.2015.00698

10. Denby K, Gehring C. Engineering drought and salinity tolerance in plants: lessons from genome-wide expression profiling in Arabidopsis. Trends in Biotechnology. 2005; 23(11):547-552.

11. De Lacerda CF, Cambraia J, Oliva MA, Ruiz HA, Prisco JT. Solute accumulation and distribution during shoot and leaf development in two sorghum genotypes under salt stress. Environmental and Experimental Botany. 2003; 49(2):107-120.

12. Farquhar G, Ehleringer J, Hubick KT. Carbon isotope discrimination and photosynthesis. Ann. Rev. Plant Physiol. Mol. Biol. 1989; 40:503-537. 
13. Fernandes DMD, Jolivet Y, Rocha AF, Gomes FE, Silva LM, Dizengremel P. Effect of salt stress on mitocondrial energy metabolism of Vigna unguiculata cultivars differing in $\mathrm{NaCl}$ tolerance. Plant Physiol Biochem. 1994; 32:405-412.

14. Flowers TJ. Improving crop salt tolerance. Journal of Experimental Botany. 2004; 55(396):307-319.

15. Flowers TJ, LaÈuchli A. Sodium versus potassium: substitution and compartmentation. In: LaËuchli A, Bieleski RL (eds) Encyclopedia of plant physiology, new series, vol 15b, inorganic plant nutrition. Springer, Berlin, 1983, pp. 651-681.

16. Foolad MR. Recent advances in genetics of salt tolerance in tomato. Plant Cell Tiss. Org. 2004; 76:101-119.

17. Gadalla AM, Hamdy A, Galal YGM. Use of saline irrigation water for production. 2007; 2:85-97.

18. Gupta N, Meena SK, Gupta S, Khandelwal S. Gas Exchange, Membrane Permeability, and Ion Uptake in Two Species of Indian Jujube Differing in Salt Tolerance. Photosynthetica. 2002; 40:535-539.

19. Hoang TML, Williams B, Khanna H, Dale J, Mundree SG. Physiological basis of salt stress tolerance in rice expressing the anti- apoptotic gene SfIAP. Funct. Plant Biol. 2014; 41:1168-1177.

20. Hasegawa PM, Bressan RA, Zhu JK, Bohnert HJ. Plant Cellular and Molecular Responses to High Salinity. Annual Review of Plant Physiology and Plant Molecular Biology. 2000; 51(1):463-499.

21. Jackson ML. Soil Chemical Analysis. Prentice-Hall of India Private Limited, New Delhi, 1973, 1-498.

22. Jamil M, Ashraf M, Rehman S, Ahmad M, Rha ES. Salinity induced changes in cell membrane stability, protein and RNA contents. 2012; 11(24):6476-6483.

23. Kao WY, Tsai TT, Shih CN. Photosynthetica. 2003; 41:415.

24. Khan RU, Rashid A, Khan A. Effect of cutting chickpea at different dates on green fodder and seed yield under rainfed condition. Pakistan J Biol. Sci. 1999; 2(2):347349

25. Khan MA, Ungar IA, Showlter AM. The effect of salinity on growth, water status, and ion content of a leaf succulent perennial halophyte, Suaeda fruticosa (L.) Forssk. J Arid Environ. 2000; 45:72-85

26. Kitajima K, Fenner M. Ecology of seedling regeneration In: Fenner M (ed) Seeds: the ecology of regeneration in plant communities, 2nd edn. CABI Publishing, Wallingford, UK, 2000, 331-359.

27. Kumawat KR, Gothwal DK, Kumawat S, Kumawat R, Choudhary M. Determination of salinity tolerance in lentil (Lens culinaris M.) seedlings using salt tolerance index. International Journal of Chemical Studies. 2017; 6(1):1584-1589.

28. Lee MH, Cho EJ, Wi SG, Bae H, Kim JE, Cho JY et al. Divergences in morphological changes and antioxidant responses in salt-tolerant and salt-sensitive rice seedlings after salt stress. Plant Physiol. Biochem. 2013; 70:325335 .

29. Lilley JM, Ludlow MM, McCouch SR, O'Toole JC. Locating QTL for osmotic adjustment and dehydration tolerance in rice. Journal of Experimental Botany. 1996; 47:1427-1436.

30. Longstreth DJ, Nobel PS. Salinity effects on leaf anatomy. Plant Physiology. 1979; 63:700-703.

31. Lopez AR, Yamada S, Yamanouchi M. Comparison of sodium uptake by and transport in detached plant parts among several crops. Soil Sci Plant Nutr. 1999; 45:659668.

32. Maher L, Armstrong R, Connor D. Salt tolerant lentils - a possibility for the future? Proceedings of the 11th Australian Agronomy Conference: Feb. 2003; (2):9-12.

33. Marschner H. Mineral nutrition in higher plants. Wd Ltd. The Greystone Press, Antrim, Northern Ireland, 1986.

34. Mitsuya S, Takeoka Y, Miyake H. Effects of sodium chloride on foliar ultrastructure of sweet potato (Ipomoea batatas Lam.) plantlets grown under light and dark conditions in vitro. J Plant Physiol. 2000; 157:661-667.

35. Mondal MMA, Puteh AB, Malek MA, Roy S, Yusop MR. Contribution of morpho-physiological traits on yield of lentil (Lens culinaris Medik.). Australian Journal of Crop Science. 2013; 7(8):1167-1172.

36. Monem AE, Sharaf M. Tolerance of five genotypes of lentil to NaCl-salinity stress. New York Sci. J. 2008; 1:70-80.

37. Munns R. Comparative physiology of salt and water stress. Plant, Cndell and Environment. 2002; 25:239-250.

38. Munns R. Genes and salt tolerance: bringing them together. New Phytologist. 2005; 167(3):645-663.

39. Pareek-Singla SL, Grover A. Salt responsive proteins/ genes in crop plants. In: Jaiwal PK, Singh RP, Gulati A. (eds.): Strategies for Improving Salt Tolerance in Higher Plants. Oxford and IBH Publishing Co., New Delhi, 1997.

40. Parida AK, Das AB. Salt tolerance and salinity effect on plants: a review. Ecotoxicol. Environ. Saf. 2005; 60:324349.

41. Rengasamy P. World salinization with emphasis on Australia. J Exp. Bot. 2006; 57:1017-1023.

42. Sairam RK. Effect of moisture stress on physiological activities of two contrasting wheat genotypes. Ind. J Exp. Biol. 1994; 32:594-597.

43. Sestak Z, Jarvi PG, Catsky J. Criteria for the selection of suitable methods. p. 1-48. In Z. Sestak, P.G. Jarvis, and J. Catsky (ed.) Plant photosynthetic production manual of methods.W. Junk Publishing Co., The Hague, 1971.

44. Sidari M, Santonoceto C, Anastasi U, Preiti G, Muscolo A. Variations in four genotypes of lentil under $\mathrm{NaCl}$ salinity stress. American Journal of Agricultural and Biological Science. 2008; 3(1):410-416.

45. Singh D, Singh CK, Kumari S, Tomar RSS, Karwa S, Singh R, Pal M. Discerning morpho-anatomical, physiological and molecular multiformity in cultivated and wild genotypes of lentil with reconciliation to salinity stress. PLoS One, 2017, 12(5).

46. Sudhakar P, Latha P, Babu AM. Evaluation of sugarcane genotypes for water use efficiency and thermo stability tolerance under imposed moisture stress at formative stage. Sugar Tech. 2010; 12:72-75.

47. Tesfaye A, Petros Y, Zeleke H. Effect of Salinity on Yield and Yield Related traits of some Accessions of Ethiopian Lentil (Lens culinaris M.) under Greenhouse Conditions. International journal of technology enhancements and emerging engineering research. 2014; 2(10):10-17.

48. Tester M, Davenport R. Na+ tolerance and $\mathrm{Na}+$ transport in higher plants. Ann Bot. 2003; 91:503-527.

49. Tejera NA, Soussi M, Lluch C. Physiological and nutritional indicators of tolerance to salinity in chickpea plants growing under symbiotic conditions. Environmental and Experimental Botany. 2006; 58:1724. 
50. Turan MA, Turkmen N, Taban N. Effect of $\mathrm{NaCl}$ on stomatal resistance and proline, chlorophyll, $\mathrm{Na}, \mathrm{Cl}$, and $\mathrm{K}$ concentration of lentil plants. journal of Agronomy. 2007; 6(2):378-381.

51. Umali, Dina L. Irrigation induced salinity: a growing problem for development and the environment (English). World Bank technical paper; no. WTP 215. Washington, DC: TheWorld Bank, 1993.

52. Urbano G, Porres JM, Frias J, Vidal-Valverde C. Chapter 5 nutritional value. In:Lentil: An Ancient Crop for Modern Times. (Edited by S.S. Yadav, D. McNeil \& P.C. Stevenson) Berlin: Springer. 2007; 3:47-93.

53. Wenxue W, Bilsborrow PE, Hooley P, Fincham DA, Lombi E, Forster BP. Salinity-induced differences in growth, ion distribution and partitioning in barley between the cultivar Maythorpe and its derived mutant Golden Promise. Plant Soil. 2003; 250:183-191. 